\title{
Airway constrictor response to cotton bract extracts in the absence of endotoxin
}

\author{
M G BUCK, ${ }^{1}$ J H WALL ${ }^{2}$ AND E N SCHACHTER ${ }^{1}$ \\ From the Yale University School of Medicine, ${ }^{1}$ New Haven, CT 06510, and Southern Regional Research \\ Center, ${ }^{2}$ USDA, New Orleans, LA 70179, USA
}

ABSTRACT Crude and purified aqueous extracts of cotton bracts shown to cause airway constriction in naive subjects were assayed for endotoxin content. Pulmonary function measured by flow changes on partial expiratory flow volume curves was used to assess airway responses to the bract extracts after their inhalation by a panel of volunteers. These responses are similar to the acute responses experienced by cotton textile workers. Crude aqueous extracts from various bracts harvested before and after senescence of the cotton plant displayed endotoxin concentrations ranging widely from 0.086 to $50 \mu \mathrm{g} / \mathrm{ml}$. No correlation was found between these differences in endotoxin content and the severity of the airway constrictor response. Purifying the bract extract by a series of procedures that included precipitation of polymeric material by addition of methanol and chromatography on an anion exchange column of DEAE-Sephacel resulted in the elimination of almost all the endotoxin. The partially purified extract contained less than $1 \mathrm{ng} / \mathrm{ml}$ of endotoxin. The panel of volunteers responded to this purified bract extract, however, with a decrease in pulmonary function which was more than $60 \%$ of that seen with the crude extract of bracts. It is concluded that aqueous extracts of cotton bract contain an agent(s) other than endotoxin that causes acute airway constriction in people.

Cotton dust and cotton bract contain endotoxin, the amount of which varies widely depending, at least in part, on cotton quality, growing conditions, and growing location. ${ }^{1}$ Pernis et al suggested that byssinosis, the specific lung disease of cotton textile workers, may be due to endotoxins produced by the Gram negative bacteria normally found on cotton bracts. ${ }^{2}$ The bacterial content of the cotton bales being processed in one experiment ${ }^{3}$ and airborne microorganisms in another ${ }^{4}$ correlated with the prevalence of byssinotic symptoms. In the latter study, however, airborne endotoxin did not correlate with symptoms. In recent studies Diem et al found that decreases in pulmonary function over the work shift correlated with airborne dust concentration, not with bacterial or endotoxin concentrations. ${ }^{5}$ By contrast, Olenchock et al found in an experimental card room environment that $\mathrm{FEV}_{1}$ decreases correlated with endotoxin content in the air significantly better than with airborne dust levels, ${ }^{6}$ and Rylander et al also found a dose response relation between airborne endotoxin and decreases in $\mathrm{FEV}_{1}$ although the latter cautioned that the endotoxin levels may be only an indicator of some other agent present in the dust with which it maintains a close relation. ${ }^{7}$

Aqueous extracts of cotton bract induce an acute airway constriction in healthy subjects never before exposed to cotton dust. ${ }^{8}$ This constriction is similar in its changes of lung function parameters and its time course to the acute response experienced by textile workers. ${ }^{910}$ The response is present with both the crude aqueous extract and partially purified extracts. The agent causing the airway constriction has not yet been identified but several of its characteristics are known, including solubility in water (a characteristic of endotoxin) and a molecular weight of less than 1000 daltons ${ }^{11} 12$ (which does not characterise endotoxin). To determine the possible involvement of endotoxin in the acute airway constrictor reaction to cotton dust, the endotoxin content of the crude and purified cotton bract extracts which induce airway constriction in people was determined.

\section{Materials and methods}

PREPARATION OF COTTON BRACT EXTRACTS The flow chart in fig 1 illustrates our procedures fo 


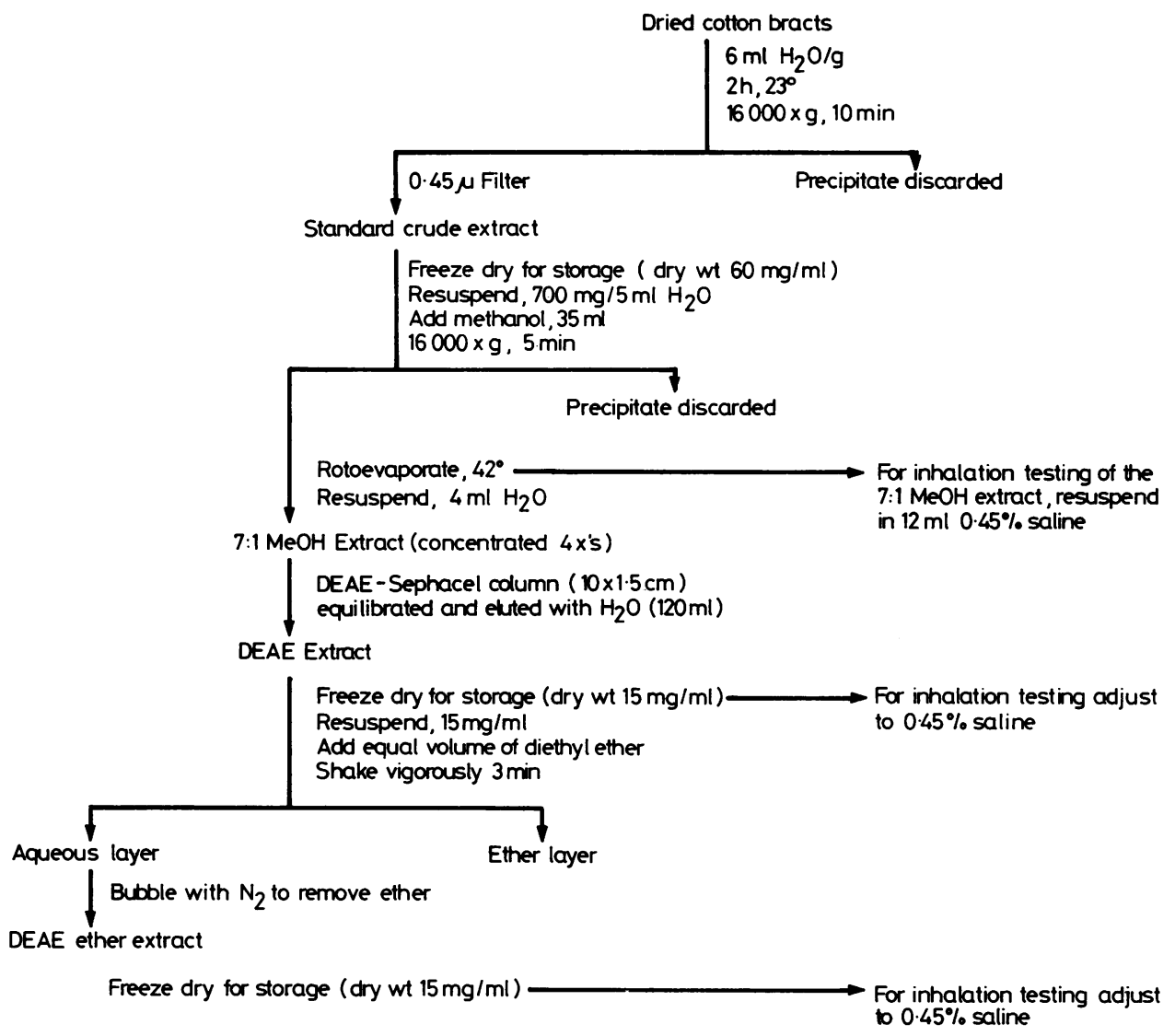

Fig 1 Procedure for preparing cotton bract extracts.

the preparation of the various bract extracts. Unless otherwise indicated, bracts were handpicked from frost killed plants just before harvest from cotton fields in the Lubbock, Texas area; they were stored at room temperature and pulverised in a Waring blender immediately before extraction. Extracts were freeze dried and stored at $-4^{\circ} \mathrm{C}$. For inhalation challenge by our subjects each extract was reconstituted with water or saline, as indicated, at a concentration equivalent to the standard crude extract. This ensured that for challenge purposes components were not concentrated as purification progressed. Pyrogen free water was used throughout.

\section{SUBJECTS}

Healthy volunteer subjects (no respiratory symptoms, no history of asthma), aged 18-45, men, women, smokers, and non-smokers, were recruited from area universities. All were naive subjects never before exposed to cotton or other textile dust of any kind. For all procedures concerning volunteers informed con- sent was obtained according to the Yale University Human Investigating Committee guidelines.

\section{ASSAY OF ACUTE AIRWAY CONSTRICTION}

While breathing normally, each subject inhaled the aerosol of cotton bract extract for 10 minutes through a Dautrebande model D 30 aerosol generator operated at 20 psi air pressure. With these conditions the output of the nebuliser is constant, and the particle size delivered has been measured to be less than $1 \mu \mathrm{m}$ in diameter. ${ }^{13}$ The aerosol was inhaled through a mouthpiece from a $\mathbf{J}$ valve. The inspiratory port of the $\mathbf{J}$ valve was attached to a $T$ piece, which in turn was connected to the aerosol generator and a $1 \mathrm{~m}$ long reservoir tube with internal diameter of $2.5 \mathrm{~cm}$.

Constriction was assayed by comparing lung function values obtained from recordings of partial and maximum expiratory flow volume (PEFV, MEFV) curves $^{14}$ before and at 30 minute intervals for a two and a half hour to three hour period after the 10 minute inhalation of the aerosolised extract. These 
Table 1 Endotoxin content and airway constrictor activity of cotton bract

\begin{tabular}{|c|c|c|c|c|c|}
\hline \multirow[t]{2}{*}{ SCE from samples } & \multirow{2}{*}{$\begin{array}{l}\text { Drywt of } \\
\text { SCE/ml }\end{array}$} & \multicolumn{2}{|l|}{ Endotoxin } & \multirow{2}{*}{$\begin{array}{l}\text { MEF } 40 \%(P) \% \text { decrease } \\
(\text { Mean } \pm S E M)\end{array}$} & \multirow{2}{*}{$\begin{array}{l}\text { Comparative } M E F \\
40 \%(P) \text { changes } \\
(\%)\end{array}$} \\
\hline & & $(\mu g / m l S C E)$ & ( $\mu g / g$ bract $)$ & & \\
\hline $\begin{array}{l}\text { Frost killed bracts } 1979 \text { harvest (Texas) } \\
\text { Brown bracts, } 1981 \text { harvest (Texas) } \\
\text { Green bracts, air dried } 1981 \text { harvest }\end{array}$ & $\begin{array}{l}60 \cdot 0 \\
12 \cdot 7\end{array}$ & $\begin{array}{l}36 \\
50\end{array}$ & $\begin{array}{l}216 \\
300\end{array}$ & $\begin{array}{l}36 \cdot 0 \pm 4 \cdot 4(n=8) \\
17 \cdot 5 \pm 4 \cdot 5(n=8)\end{array}$ & $\begin{array}{l}100 \\
48 \cdot 6\end{array}$ \\
\hline $\begin{array}{l}\text { (Texas) } \\
\text { Fresh green bracts, } 1981 \text { harvest }\end{array}$ & $41 \cdot 2$ & 0.25 & $1 \cdot 50$ & $12 \cdot 8 \pm 4 \cdot 0(n=8)$ & $35 \cdot 6$ \\
\hline (New Orleans) & $40 \cdot 0$ & 0.086 & 0.516 & $25 \cdot 3 \pm 5 \cdot 1(\mathrm{n}=8)$ & $82 \cdot 0$ \\
\hline
\end{tabular}

SCE $=$ Standard crude extract.

were recorded with a pneumotachograph integrator device $^{15}$ and an $\mathrm{XY}$ recorder; ordinate: expiratory flow rates, abscissa: expired volume. The subject first inspired to about $65 \%$ of the vital capacity (VC) - the exact level is not crucial and may vary from about $60 \%$ to $75 \%$ of $\mathrm{VC}$ - the subsequent forced expiration to residual volume yielded the PEFV curve. Without interruption, the subject next inspired maximally, and then again expired forcefully and maximally to residual volume, recording the MEFV curve. Forced vital capacity (FVC) and forced expiratory volume in one second $\left(\mathrm{FEV}_{1}\right)$ were measured from the MEFV curve. MEF $40 \%(\mathrm{P})$ is the instantaneous flow rate on the PEFV curve measured at the lung volumes corresponding to $40 \%$ of the forced vital capacity (maximum inspiration $=100 \%$ FVC). To compare responses to bract extract aerosol the MEF $40 \%(\mathrm{P})$ value was used where the $40 \% \mathrm{VC}$ volume for each subject day was computed as an average from five control (before aerosol inhalation) MEFV curves of that day. This $40 \%$ volume was used throughout the test period.

Each subject was screened initially to determine responder status. For this, the crude aqueous extract (made from the frost killed bracts from the Lubbock, Texas, 1979 harvest) was used as the standard for screening all subjects. Responders to cotton bract were defined as subjects whose MEF $40 \%(\mathrm{P})$ decreased $20 \%$ or more after inhalation challenge with the standard extract. ${ }^{16}$. This value has been selected in previous studies because of its ability consistently to identify mild airway constrictor responses. Responders were selected to assay for constrictor activ- ity in unknown extracts. Non-responders - that is subjects who showed a maximal decrease in MEF $40 \%(\mathrm{P})$ of $20 \%$ or less-were excluded.

Saline, administered in the same manner as the bract extract, was used as a control.

\section{ENDOTOXIN DETERMINATION}

The Limulus amoebocyte lysate test performed according to the Associates of Cape Cod, Inc (PO Box 224, Woods Hole, MA 02543) was used to determine endotoxin content of bract extracts. Serial dilutions of each bract extract were prepared with pyrogen free water. Equal aliquots $(0 \cdot 1 \mathrm{ml})$ of each dilution and lysate were mixed in tubes and incubated in a water bath at $37^{\circ} \mathrm{C}$ for one hour. The tubes were inverted and the last dilution to give a stable clot was compared with a similar clot formation in a dilution series of known amounts of commerical endotoxin (LPS Escherichia coli serotype O 113, lot no 13, from Associates of Cape Cod, Inc). The water used to make the dilutions was used as a negative control.

\section{Results}

Table 1 shows the endotoxin content of crude extracts prepared from four different bract samples. Two samples, the frost killed 1979 harvest and the brown bracts 1981 harvest, which were picked after the plant had dried and turned brown, contained 36 and 50 $\mu \mathrm{g} / \mathrm{ml}$ endotoxin respectively.

A third sample prepared from bracts picked from the same field as the brown bracts 1981 harvest, but picked while the plants were still alive and green and

Table 2 Airway constrictor activity of purified cotton bract extracts

\begin{tabular}{|c|c|c|c|c|}
\hline Sample & $N o^{*}$ & $\begin{array}{l}\% \text { Airway constrictor activity } \dagger \\
(\text { Mean } \pm S E M)\end{array}$ & Dry wt $(m g / m l)$ & Endotoxin (ng/ml) \\
\hline $\begin{array}{l}\text { SCE } \\
7: 1 \mathrm{MeOH} \text { extract } \\
\text { DEAE extract } \\
\text { Ether extracted DEAE extract }\end{array}$ & $\begin{array}{r}22 \\
16 \\
7\end{array}$ & $\begin{array}{l}100 \\
61 \pm 5 \\
58 \pm 8 \\
63 \pm 10\end{array}$ & $\begin{array}{l}60 \\
24 \\
15 \\
15\end{array}$ & $\begin{array}{r}36000 \\
1 \cdot 3 \\
0 \cdot 3 \\
0 \cdot 2\end{array}$ \\
\hline
\end{tabular}

SCE $=$ Standard crude extract.

*Number of subjects tested with sample.

† $\triangle \mathrm{MEF} 40 \%(\mathrm{P})_{\text {purified extract }} \times 100$.

$\triangle \mathrm{MEF} 40 \%(\mathrm{P})_{\text {SCE }}$ 
Table 3 . Airway constrictor activity and endotoxin content of DEAE fractions of bract extracts

\begin{tabular}{|c|c|c|c|c|}
\hline Sample & $N o^{*}$ & $\begin{array}{l}\triangle M E F 40 \%(P) \dagger \\
(M e a n \pm S E M)(\%)\end{array}$ & $\begin{array}{l}\% \text { Airway constrictor } \\
\text { activity } \ddagger\end{array}$ & Endotoxin ( $\mathrm{ng} / \mathrm{ml})$ \\
\hline $\begin{array}{l}\text { SCE } \\
\text { DEAE, Fr no } 1 \\
\text { DEAE, Fr no } 2 \\
\text { DEAE, Fr no } 3\end{array}$ & $\begin{array}{l}5 \\
3 \\
5 \\
3\end{array}$ & $\begin{array}{l}-34 \pm 6 \\
+4 \pm 4 \\
-24 \pm 6 \\
+3 \pm 2\end{array}$ & $\begin{array}{r}100 \\
0 \\
71 \\
0\end{array}$ & $\begin{array}{r}36000 \\
0.5 \\
0.3 \\
0.4\end{array}$ \\
\hline
\end{tabular}

SCE $=$ Standard crude extract.

* Number of subjects tested with sample.

tChange in MEF $40 \%(P)$ after exposure to sample.

$\ddagger \triangle \mathrm{MEF} 40 \%(\mathrm{P})$ purified extract $\times 100$.

$\triangle \mathrm{MEF} 40 \%(\mathrm{P})$ sCE

then air dried, contained about 200 times less endotoxin (only $0.25 \mu \mathrm{g} / \mathrm{ml}$ ). Even less endotoxin was found in the fourth sample of bracts which was picked while still green and immediately freeze dried to prevent senescence from occurring. The extracts from these bracts contained only $0.086 \mu \mathrm{g} / \mathrm{ml}$ endotoxin.

The ability of these extracts to induce airway constriction in people was tested in a panel of eight volunteers who were known to be responders. The results are included in table 1 . Responder status was determined by screening each volunteer with the standard crude extract of bracts prepared from the frost killed 1979 harvest. Compared with the 1979 harvest, the 1981 brown bracts were only about half as active $(48.6 \%)$ even though they contained slightly more endotoxin. The green bracts from the 1981 harvest exhibited an airway constricting activity of $35.6 \%$, only somewhat less than the brown bracts, whereas the endotoxin content was less by several orders of magnitude. The extract from the fresh green bracts, while containing the least amount of endotoxin, was more active in inducing airway constriction than either the air dried green or the brown bracts from the 1981 harvest. Its percentage activity was 82 , close to that of the frost killed 1979 bract.

The crude aqueous extract from the 1979 harvest was partially purified in a series of sequential steps, the first of which was the addition of methanol. This resulted in the precipitation of a large amount of material including presumably proteins and other large nolecules. As shown in table 2, the supernatant solution from this step, the 7:1 $\mathrm{MeOH}$ extract had a dry weight of $24 \mathrm{mg} / \mathrm{ml}$ reduced from the original $60 \mathrm{mg} / \mathrm{ml}$. The airway constricting activity of this preparation was $61 \%$ that of the original extract, and the endotoxin concentration was at the nanagram level $(1.3 \mathrm{ng} / \mathrm{ml})$ compared with $36 \mu \mathrm{g} / \mathrm{ml}$ in the original crude extract. The precipitate from the $7: 1$ $\mathrm{MeOH}$ extract thus contained most of the endotoxin and accounted for only a $16 \%$ loss of activity.

The 7:1 $\mathrm{MeOH}$ extract was purified further by passing it through a DEAE anion exchange column. The fraction not bound by the column, designated the DEAE extract, showed additional decreases in dry weight material to $15 \mathrm{mg} / \mathrm{ml}$ and endotoxin content to $0.3 \mathrm{ng} / \mathrm{ml}$. These changes resulted in no further de-

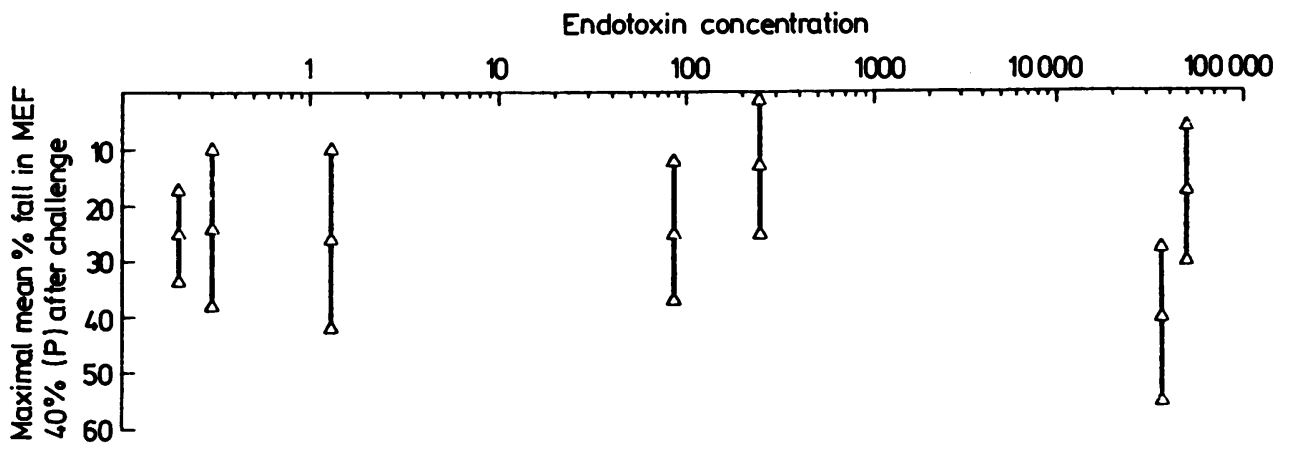

Fig 2 Mean \% fall in MEF 40\% (P) after inhalation challenge versus endotoxin concentration (ng/ml) in various cotton bract extracts. Extracts compared were those listed in tables 1 and 2 . In order of decreasing endotoxin content they are SCE of brown bracts (extreme right), SCE of frost killed 1979 bracts, SCE of green bracts, SCE of fresh green bracts, 7:1 MeOH extract, DEAE extract, and ether extracted DEAE extract (extreme left). 
crease in airway constrictor activity (see table 2). Extracting the DEAE extract with diethyl ether caused little change in dry weight, endotoxin content, or constrictor activity but did remove lacinilene compounds.

The DEAE extract was fractionated into three fractions as it emerged from the column. Airway constrictor activity was associated exclusively with the second fraction despite the finding that all the fractions contained essentially the same low level (less than $1 \mathrm{ng} / \mathrm{ml}$ ) of endotoxin. The results are presented in table 3. Results with the standard crude extract also are included for comparison. Subsequent assays performed in another laboratory confirmed these endotoxin values. ${ }^{17}$

To confirm that the purification scheme used for the bract extract does remove endotoxin, a solution of $180 \mathrm{ng} / \mathrm{ml} E$ coli endotoxin (from a commercial source) was carried through the scheme. With the addition of methanol no precipitation was observed. Nevertheless, after passage of the $180 \mathrm{ng} / \mathrm{ml}$ solution through the DEAE anion exchange column less than $0.2 \mathrm{ng} / \mathrm{ml}$ endotoxin remained in the solution. This confirms that endotoxin is consistently removed by the procedures and conditions used to purify our cotton bract extracts.

In order further to quantitate the relation between bract endotoxin content and airway constrictor re- sponse, the mean percentage fall in MEF $40 \%(P)$

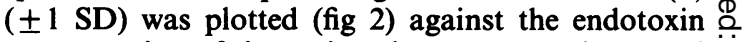
concentration of the various bract preparations used $\vec{\Rightarrow}$ for each of the panels of subjects. As may be appre- $\stackrel{0}{+}$ ciated, over a several thousandfold variation in concentration, endotoxin did not influence the constrictor response.

Further, in table 4 , the response between the bract $\frac{\Phi}{\varnothing}$ preparations was compared in the same groups of individuals. The horizontal and vertical headings list the bract preparations and their endotoxin content. Numbers in the upper right of the diagram represent the average percentage difference in the MEF $40 \%(\mathrm{P})$ drop between the bract preparations (positive differences indicate that the preparations with the higher endotoxin content have a greater constrictor $\omega$ effect, negative differences indicate that the prepara- $\rightarrow$ tions with the lower endotoxin content have the greater constrictor effect). The second number in each comparison represents the number of paired comparisons.

The set of numbers in the lower left of the diagram $\frac{T}{0}$ indicates the $t$ statistic for the paired comparison, the number of degrees of freedom $(\mathrm{df})$, and the $\mathrm{p}$ value. $\vec{\varphi}$ Five of these comparisons were statistically significant. In these groups it is apparent that the standard crude extract is consistently more potent

Table 4 Differences in bronchoconstrictor responses (percentile in $M E F 40 \%(P)$ ) between bract preparations (Mean $\pm 1 S D$ )

\begin{tabular}{|c|c|c|c|c|c|c|c|}
\hline $\begin{array}{l}\text { Sample* } \\
\text { Endotoxin (ng) }\end{array}$ & $\begin{array}{l}\text { Brown } \\
50 \times 10^{3}\end{array}$ & $\begin{array}{l}S C E \\
36 \times 10^{3}\end{array}$ & $\begin{array}{l}\text { Green } \\
0.25 \times 10^{3}\end{array}$ & $\begin{array}{l}\text { Fresh green } \\
0.086 \times 10^{3}\end{array}$ & $\begin{array}{l}M E O H \\
1 \cdot 3\end{array}$ & $\begin{array}{l}D E A E \\
0 \cdot 3\end{array}$ & $\begin{array}{l}D E A E \\
\text { ether } \\
0-2\end{array}$ \\
\hline $\begin{array}{l}\text { Brown } \\
50 \times 10^{3}\end{array}$ & & $-19 \pm 10 \cdot 1$ & $+5 \pm 12 \cdot 9$ & & & & \\
\hline $\begin{array}{l}\text { SCE } \\
36 \times 10^{3}\end{array}$ & $\begin{array}{l}t=5.2 \\
d f=7 \\
p<0.00001\end{array}$ & & $+\underset{8}{23 \pm 18.4}$ & $+\underset{10}{9} \pm 17 \cdot 3$ & $+\underset{22}{16} \pm 13 \cdot 5$ & $+\underset{16}{19} \pm 16 \cdot 4$ & $+15 \pm 9$ \\
\hline $\begin{array}{l}\text { Green } \\
0.25 \times 10^{3}\end{array}$ & $\begin{array}{l}t=10 \\
d f=7 \\
\text { NS }\end{array}$ & $\begin{array}{l}t=3.6 \\
d f=7 \\
p=0.0045\end{array}$ & & & & & \\
\hline $\begin{array}{l}\text { Fresh green } \\
0.086 \times 10^{3}\end{array}$ & & $\begin{array}{l}t=1.7 \\
d f=9 \\
p=0.06\end{array}$ & & & & & \\
\hline $\begin{array}{l}\text { MEOH } \\
1 \cdot 3\end{array}$ & & $\begin{array}{l}t=5 \cdot 7 \\
d f=21\end{array}$ & & & & $+8_{8} \pm 14 \cdot 3$ & \\
\hline $\begin{array}{l}\text { DEAE } \\
0 \cdot 3\end{array}$ & & $\begin{array}{l}t=4 \cdot 7 \\
d f=15 \\
p=0.00015\end{array}$ & & & $\begin{array}{l}t=1.6 \\
d f=7 \\
\text { NS }\end{array}$ & & \\
\hline $\begin{array}{l}\text { DEAE } \\
\text { ether } 0.2\end{array}$ & & $\begin{array}{l}t=4.3 \\
d f=6 \\
p=0.0026\end{array}$ & & & & & \\
\hline \multicolumn{8}{|c|}{$\begin{array}{l}\text { "Brown = Brown bracts (Texas, 1981). } \\
\text { SCE = Standard crude extract. } \\
\text { Green = Green bracts (Texas, 1981). } \\
\text { Fresh green = Green bracts (New Orleans, 1981). } \\
\text { MEOH = 7.1 Methanol extract. } \\
\text { DEAE = DEAE extract. } \\
\text { DEAE ether = DEAE extract after ether extraction. }\end{array}$} \\
\hline
\end{tabular}


than the other preparations in terms of its constrictor effect. Clearly, however, no consistent pattern may be seen with regard to the endotoxin concentration.

\section{Discussion}

Naive subjects never before exposed to cotton dust of any type respond to inhalation of crude aqueous extracts of cotton dust or bract with an acute airway constriction that has a delay of 90-120 minutes before reaching maximum. ${ }^{8}$ No fever was found associated with this response ${ }^{18}$ even though the standard crude extract contains about $36 \mu \mathrm{g} / \mathrm{ml}$ of endotoxin. Airborne respirable dust in cotton textile mills contains Gram negative bacteria as well as endotoxin, whereas the crude extracts used in this study have been sterilised by passage through a 0.45 micron filter before being administered to subjects. The question arises, is the endotoxin concentration in mill dust or bract extracts high enough to cause (or contribute to) the acute airway constriction observed? ${ }^{19}$ Two groups have studied and reported on the response of subjects to inhalation of pure endotoxin. ${ }^{2021}$ In the earlier study $40 \mu \mathrm{g}$ or $80 \mu \mathrm{g}$ of purified $E$ coli endotoxin were inhaled. Two subjects who inhaled $40 \mu \mathrm{g}$ had no response and of the eight subjects who inhaled $80 \mu \mathrm{g}$, two responded with $\mathrm{FEV}_{1}$ decreases of 17-20\% which were maximal at 30 minutes, the other six did not experience significant changes in $\mathrm{FEV}_{1}$. In a recent study Rylander's laboratory challenged 15 subjects with 4-20 $\mu \mathrm{g}$ of pure endotoxin in solution. ${ }^{21}$ Even at the higher concentration which was inhaled by four of the 15 subjects, they found no significant decreases in $\mathrm{FEV}_{1}$. It appears from these studies that only a limited number of healthy individuals are sensitive to endotoxin at concentrations as high a $80 \mu \mathrm{g}$ of pure endotoxin.

Airborne respirable dust in cotton textile mills contains $0 \cdot 02-3 \cdot 16 \mu \mathrm{g} / \mathrm{m}^{3}$ endotoxin. ${ }^{122}$ If it is assumed a worker breathes about $15 \mathrm{~m}^{3}$ during an eight hour shift he will breathe in 0.3-47 $\mu$ g endotoxin over the workday. In volunteers, where one assumes tidal breathing at a rate of 12 breaths per minute at 800 $\mathrm{ml} /$ breath for the 10 minute inhalation test period, it is estimated that each subject inhales $0.3 \mathrm{ml}$ of bract extracts. This is equivalent to inhaling $11 \mu \mathrm{g}$ of endotoxin when the standard crude extract of bracts 1979 harvest is tested and only $0.09 \mathrm{ng}$ for the purified bract extracts (DEAE extracts). These endotoxin concentrations are far below those reported ${ }^{2021}$ to cause airway constriction in people, and thus it is not surprising that no correlation was seen between endotoxin concentrations and bronchoconstrictor effects. As in these challenge studies with the bract extracts the pure endotoxin exposures were administered over a short period in contrast to the exposure of mill workers, who have a prolonged exposure and who are exposed at the same time to Gram negative bacteria as well.

Crude aqueous extracts prepared from different samples of cotton bracts showed a wide range of endotoxin content from $0 \cdot 086-50 \mu \mathrm{g} / \mathrm{ml}$. No correlation was found between the airway constrictor activity of these crude extract samples and their endotoxin content-again not surprising in view of the findings of Cavagna et $a^{20}$ and Haglind et al. ${ }^{21}$

Purified extracts, which are essentially endotoxin free $(<1 \mathrm{ng} / \mathrm{ml}$ endotoxin), retain the ability to induce airway constriction in volunteers. The less than $1 \mathrm{ng} / \mathrm{ml}$ concentration of endotoxin remaining in purified extracts is without effect. DEAE fractions collected before and after the active fraction (fraction 2) contain similar low levels of endotoxin and yet are without airway constricting activity. After the three sequential purification steps, about $63 \%$ of the constricting activity remains. Thus aqueous extracts of cotton bract contain an agent(s) other than endotoxin which causes acute airway constriction in people.

Since cotton mill dust contains a high proportion of bract material, ${ }^{23}$ the bract constrictor agent(s) found in aqueous extracts is undoubtedly present in mill dust as well. Attempts to compare the relative dose of bract aqueous extract and respirable mill dust are rough approximations at best. Estimates of the proportion of bract in mill dust vary $\left(32-52 \%^{23}\right)$ and no data are available to know the proportion of the airway constricting agent(s) extracted into the initial aqueous extract, the standard crude extract. The volume of extract inhaled by volunteers is about $0.3 \mathrm{ml}$ prepared from $50 \mathrm{mg}$ of bract. The amount of respirable mill dust inhaled by workers is $5-57 \mathrm{mg}$, assuming dust levels of $0.46-3.80 \mathrm{mg} / \mathrm{m}^{3}$ and an inhalation of $15 \mathrm{~m}^{3}$ during an eight hour workshift. ${ }^{122}$ It has not been shown that the quantities of endotoxin present in textile mill dust are sufficient alone to account for the acute airway constriction observed in mill workers. Possibly, however, where the bract constrictor agent and sublevels of endotoxin are present together, as they may be in mill dust, a synergistic action exists. ${ }^{18}$

We thank D Tyler for technical help and R V Baker and $C$ Brown (Lubbock, Texas) who supervised the collection of cotton bracts by members of Boy Scout Troop 103. We thank Dr Bob Jacobs, Cotton Incorporated, for supplying samples of bracts. This work was supported in part by Cotton Incorporated (agreement 81-491).

This paper was presented in part at the 6th Cotton Dust Research Conference (January 1982, Las Vegas, Nevada). 


\section{References}

${ }^{1}$ Rylander R, Morey P. Airborne endotoxins in industries processing vegetable fibers. Am Ind Hyg Assoc J 1982;43:811-2.

${ }^{2}$ Pernis B, Vigliani EC, Cavagna C, Finulli M. The role of bacterial endotoxins in occupational diseases caused by inhaling vegetable dusts. Br J Ind Med 1961;18:120-9.

${ }^{3}$ Rylander R, Imbus HR, Suh MW. Bacterial contamination of cotton as an indicator of respiratory effects among card room workers. Br J Ind Med 1979;36:299-304.

${ }^{4}$ Cinkotai FF, Lockwood MG, Rylander R. Airborne microorganisms and prevalence of byssinotic symptoms in cotton mills. Am Ind Hyg Assoc J 1977;38:554-9.

${ }^{5}$ Diem JE, Fischer JM, Glindmeyer HW, Abdel-Kader H, Weil H. Environmental determinants of across-shift pulmonary function change in cotton textile workers. In: Wakelyn PJ, Jacobs RR, eds. Proceedings of the 8th cotton dust research conference, Atlanta, 1984. Memphis, Tennessee: National Cotton Council, 1984:20-2.

${ }^{6}$ Olenchock SA, Castellan RM, Hankinson JL. Endotoxin contamination of cotton: area of growth/varieties. In: Wakelyn PJ, Jacobs RR, eds. Proceedings of the 8th cotton dust research conference, Atlanta, 1984. Memphis, Tennessee: National Cotton Council, 1984:64-6.

${ }^{7}$ Rylander R, Haglind P. Relation between $\mathrm{FEV}_{1}$ changes over workshift and dust/endotoxin levels. In: Wakelyn PJ, Jacobs RR, eds. Proceedings of the 7th cotton dust research conference, San Antonio, 1983. Memphis, Tennessee: National Cotton Council, 1983:17-8.

${ }^{8}$ Buck MG, Bouhuys A. Byssinosis: airway constrictor response to cotton bracts. Lung 1980;158:25-32.

${ }^{9}$ Bouhuys A, Mitchell CA, Schilling RSF, Zuskin E. A physiological study of byssinosis in colonial America. Transactions of the New York Academy of Science 1973;35:537-46.

${ }^{10}$ Bouhuys A. Byssinosis: scheduled asthma in the textile industry. Lung 1976;154:3-16.

${ }^{11}$ Buck MG, Bouhuys A. A purified extract from cotton bracts induces airway constriction in humans. Chest 1981;79:43-9S.

12 Douglas JS, Duncan PG, Zuskin E. Characterisation of textile dust extracts: II bronchoconstriction in man. $\mathrm{Br} \mathrm{J}$ Ind Med 1984;41:70-6.

13 Dautrebande L. Experimental observations of the participation of alveolar spaces in airway dynamics. In: Bouhuys A, ed. Airway dynamics. Springfield, Ill: Charles C Thomas, 1970:153.

${ }^{14}$ Bouhuys A, Hunt VR, Kim BM, Zapletal A. Maximum expiratory flow rates in induced bronchoconstriction in man. $J$ Clin Invest 1969;48:1159-68.

${ }^{15}$ Virgulto J, Bouhuys A. Electronic circuits for recording of maximum expiratory flow-volume (MEFV) curves. J Appl Physiol 1973;35:145-7.

${ }^{16}$ Schachter EN, Brown S, Zuskin E, et al. The effect of mediator modifying drugs in cotton bract-induced bronchospasm. Chest 1981;79:73-7S.

${ }^{17}$ Mundie TG, Buck MG, Cardova-Salinas M, Neuman RE, Ainsworth SK. In vitro bioassays and cotton bract induced bronchoconstriction in human volunteers: a comparative study. In: Wakelyn PJ, ed. Proceedings of the 6th cotton dust research conference, Las Vegas, Nevada, 1982. Memphis, Tennessee: National Cotton Council, 1982:34-5.

${ }^{18}$ Buck MG. Cotton bract and acute airway constriction in humans. In: Montalvo J, ed. Cotton dust in the work place. ACS Symposium Series 1982;189:187-202.

${ }^{19}$ Antweiler $\mathrm{H}$. Histamine liberation by cotton dust extracts: evidence against its causation by bacterial endotoxin. $\mathrm{Br} \mathrm{J}$ Ind Med 1961;18:130-2.

${ }^{20}$ Cavagna G, Foa V, Vigliani EC. Effects in man and rabbits of inhalation of cotton dust or extracts and purified endotoxins. $\mathrm{Br}$ $J$ Ind Med 1969;26:314-21.

${ }^{21}$ Haglind P, Bake B, Rylander R. Effects of endotoxin inhalation challenges in humans. In: Wakelyn PJ, Jacobs RR, eds. Proceedings of the 8th cotton dust research conference, Atlanta, 1984. Memphis, Tennessee: National Cotton Council, 1984:105-7.

${ }^{22}$ Cinkotai FF, Lockwood MG, Rylander R. Airborne microorganisms and prevalence of byssinotic symptoms in cotton mills. Am Ind Hyg Assoc J 1977;38:554-9.

${ }^{23}$ Morey PR, Sasser PE, Bethea RM, Kopetzky MT. Variation in trash composition in raw cottons. Am Ind Hyg Assoc J 1976;37:407-11. 